\title{
SEJARAH DESA TALAGA BESAR KECAMATAN TALAGA RAYA KABUPATEN BUTON TENGAH (1977-2017)
}

\author{
HISTORY OF VILLAGE TALAGA BESAR SUBDISTRIC TALAGA RAYA \\ MIDDLE BUTON REGENCY (1977-2017) \\ Kartika Dewi $^{2}$ \\ e-mail: kartikadewi@yahoo.com
}

Dade Preat Utarti ${ }^{3}$

e-mail: dadeprat.untarti@uho.ac.id

${ }^{1)}$ Hasil Penelitian Tahun 2018, 2) Alumni Jurusan Pendidikan Sejarah, ${ }^{3)}$ Dosen FKIP UHO

\begin{abstract}
ABSTRAK: Permasalahan pokok dalam penelitian ini adalah: (1) Apa latar belakang terbentuknya Desa Talaga Besar Kecamatan Talaga Raya Kabupaten Buton Tengah? (2) Bagaimana berkembangan Desa Talaga Besar Kecamatan Talaga Raya Kabupaten Buton Tengah Tahun 1977-2017? Metode sejarah tersebut adalah: (a) Pemilihan topik (b) Heuristik (Pengumpulan Data) (c) Verifikasi (Kritik Sejarah) (d) Interpretasi (e) Historiografi (kritik sejarah). Hasil penelitian ini menunjukan bahwa: (1) Desa Talaga Besar awalnya hanya dijadikan tempat untuk berkebun atau bercocok tanam, misalnya menanam jagung dan ubi kayu sebagai makanan pokok masyarakat setempat dan pada umumnya masyarakat Buton. Karena seiring berjalannya waktu dan peradaban serta jumlah penduduk semakin bertambah banyak. Pemerintah daerah berinisiatif memekarkan desa Talaga Besar menjadi desa definitif. Faktor-faktor yang mendukung terbentuknya Desa Talaga Besar ini ialah: (a) Adanya peranan pemimpin yang selalu memberikan motivasi kepada warga untuk aktif dalam setiap kegiatan yang sifatnya membangun. (b) Faktor pendukung diantaranya faktor geografis (wilayah), faktor demografi (penduduk), dan faktor ekonomi. (2) Perkembangan Desa Talaga Besar dalam bidang ekonomi, sebagian besar masyarakat Talaga Besar menggantungkan hidupnya di bidang pertanian dan perdagangan yang telah dilakukan dan dikembangkan secara turun temurun. Di bidang sosial, hubungan sosial kemasyarakatan antara warga Desa Talaga Besar cukup harmonis. Di bidang pendidikan, perkembangan pendidikan di Desa Talaga Besar pada khususnya dan Kecamatan Talaga Raya pada umumnya mengalami perkembangan pendidikan yang boleh dikatakan sudah cukup baik dan infrastruktur lebih baik bila dibandingkan dengan keadaan sebelumnya.
\end{abstract}

\section{Kata Kunci: Sejarah, Desa, Talaga Besar}

ABSTRACT: The main problems in this study are: (1) What is the background of the formation of Talaga Besar Village, Talaga Raya District, Buton Tengah Regency? (2) How did the development of Talaga Besar Village, Talaga Raya District, Buton Tengah Regecy Year 1977-2017? The historical methods are: (a) Selection of topics (b) Heuristics (Data Collection) (c) Verification (Historical Criticism) (d) Interpretation (e) Historiography (historical criticism). The results of this study indicate that: (1) Talaga Besar Village was originally only used as a place for gardening or farming, for example planting corn and cassava as a staple food for the local community and in general the Buton people. Because over time and civilization as well as the population increases. The regional government took the initiative to split the village of Talaga Besar into a definitive village. The factors that support the formation of the Talaga Besar Village are: (a) There is a role of leaders who always motivate citizens to be active in any constructive activity. (b) Supporting factors include geographical factors (region), demographic factors (population), and economic factors. (2) The development of Talaga Besar Village in the economic field, most of the Talaga Besar people depend their lives on agriculture and trade which have been carried out and developed for generations. In the social field, social relations between the people of Talaga Besar Village are quite harmonious. In the field of education, the development of education in the village of Talaga Besar in particular and the Talaga Raya sub-district in general experienced a development of education which was arguably quite good and the infrastructure was better when compared to the previous situation.

\section{Keywords: History, Village, Great Talaga}




\section{PENDAHULUAN}

Pembangunan bangsa Indonesia yang telah berlangsung merupakan bagian dari proses pembangunan yang telah direncanakan secara bertahap dan berkesinambungan. Hal ini dilakukan sebagai upaya untuk mengembangkan amanah dalam mewujudkan cita-cita proklamasi kemerdekaan bangsa Indonesia 17 Agustus 1945, yakni untuk mencapai suatu masyarakat yang adil dan makmur berdasarkan Pancasila dan Undang-Undang Dasar 1945.

Dewasa ini pemerintah dan bangsa Indonesia melaksanakan pembangunan yang direncanakan, yang mengarah kepada pembangunan suatu masyarakat modern yang terbuka. Pembangunan itu telah dilaksanakan berdasarkan atas perencanaan dengan menggunakan hasil ilmu pengetahuan dan teknologi. Perencanaan yang mendasari usaha pembangunan itu adalah integral, yang memperhatikan segala aspek kehidupan masyarakat, aspek ekonomi, kesejahteraan material dan spiritual, intelektual dan emosional, aspek politik, ekonomi, dan keamanan dalam bidang luar dan dalam negeri nasional (Harsono, 1984: 246).

Pembangunan pedesaan adalah suatu strategi pembangunan yang dirancang bagi peningkatan kehidupan ekonomi dan sosial masyarakat yaitu masyarakat yang kurang mampu yang berada di pedesaan. Karena pembangunan di pedesaan bertujuan untuk mengurangi kemiskinan, maka usaha ini harus secara jelas dan tegas kearah peningkatan produksi dan produktivitas. Satu faktor yang mempercepat terjadinya pemekaran desa ini adalah fenomena pertumbuhan penduduk di daerah pedesaan yang terus meningkat dengan senantiasa memperhatikan potensi-potensi desa, sarana dan prasarana serta kehidupan sosial ekonomi masyarakat desa tersebut. Selain itu, faktor lain yang mempercepat terjadinya pembentukan desa karena kurangnya perhatian dari desa-desa induk seperti pengalokasian berbagai aset dan sumber daya kepada seluruh dusun, seperti pembangunan infrastruktur, pemberdayaan masyarakat, peningkatan pelayanan kepada masyarakat yang seakan tidak berjalan secara merata.

Pembangunan Desa tidak terlepas dari sejarah desa itu sendiri, setelah mengetahui jenis sejarah sebagai ilmu, maka perihal penjelasan sejarah sehubungan dengan jenis ilmu. Ada tiga hal yang harus kita pahami yaitu: (1) penjelasan sejarah adalah hermeneutics dan verstehen, menafsirkan dan mengerti, (2) penjelasan sejarah adalah penjelasan tentang waktu yang memanjang, (3) penjelasan sejarah adalah penjelasan tentang peristiwa tunggal (Kuntowijoyo, 2003: 210). Desa adalah kesatuan masyarakat hukum yang memiliki kewenangan untuk mengatur dan mengurus kepentingan masyarakat setempa berdasarkan asal-usul dan adat istiadat setempat yang diakui dalam sistem pemerintahan nasional dan beradadi daerah kabupaten. Desa juga dapat dikatakan sebagai suatu hasil perpaduan antara kegiatan sekelompok manusia dengan lingkungannya. Hasil dari perpaduan itu ialah suatu wujud atau kenampakan dimuka bumi yang ditimbulkan oleh unsur-unsur fisiografi, sosial, ekonomi, politik dan kultural yang saling berinteraksi antar unsur tersebut dan juga dalam hubungannya dengan daerah-daerah lain. Desa dalam arti umum juga dapat dikatakan sebagai permukiman manusia yang letaknya diluar kota dan penduduknya bermatapencaharian dengan bertani atau bercocok tanam serta menjadi nelayan (Sapoetra, 1986: 21).

Pengertian desa dalam kamus besar Bahasa Indonesia istilah desa diartikan sebagai kelompok rumah diluar kota yang merupakan suatu kesatuan kampung dusun yang terpencil, istilah desa selalu diasosiasikan dengan dua gambaran utama. Desa secara sosiologis suatu komunitas dalam suatu geografis tertentu yang antara mereka saling mengenal dengan baik, dengan corak kehidupan yang relatif homogen dan banyak tergantung dari alam. Oleh karena itu ada tiga unsur utama yaitu penduduk, tanah dan bangunan. Untuk itu lambat laun mengalami perubahan maka desa sebagai pola pemukiman bersifat dinamis, adapun desa dalam arti administratif oleh Sutardjo Kartohadikusumo dijelaskan sebagai suatu kesatuan hukum dimana bertempat tinggal suatu masyarakat yang berkuasa mengadakan pemerintahan sendiri (Siagian, 1998: 67).

Nurcholis mengemukakan bahwa desa merupakan suatu wilayah yang dialami oleh sejumlah penduduk yang saling mengenal atas dasar hubungan kekerabatan dan/atau kepentingan 
politik, sosial ekonomi, dan keamanan yang dalam pertumbuhan menjadi kesatuan masyarakat hukum berdasarkan adat sehingga tercipta ikatan lahir dan batin antara masing-masing warganya, umumnya warganya hidup dari pertanian, mempunyai hak mengatur rumah tangga sendiri, dan secara administratif berada di bawah pemerintahan kabupaten/kota (Jumriatin dan Mursidin T, 2019: 58)

Pemekaran sebuah desa diharapkan dapat membangun kemandirian masyarakat dalam mengelola potensi daerah mereka sendiri yang nantinya dapat merangsang kegeliatan ekonomi masyarakat guna membangun kesejahteraan masyarakat desa. Karena itu, aspek-aspek pendukungnya juga mestinya tidak boleh dilupakan dalam meninjau kelayakan sebuah desa untuk dimekarkan seperti potensi wilayah dan sumber daya manusia. Begitu pula dengan layanan transportasi yang memadai yang memungkinkan bagi masyarakat setempat untuk dapat melakukan interaksi sosial ekonomi dengan penduduk desa lain atau masyarakat di daerah lain. Oleh karena itu faktor tersebut perlu untuk selalu dipertimbangkan dalam pemekaran desa, karena bagaimanapun juga pembentukan sebuah desa harusnya dapat membawa dampak kesejahteraan bagi kehidupan sosial ekonomi masyarakat setempat.

Kuntowijoyo mengemukakan bahwa mengkaji pokok-pokok permasalahan sejarah pedesaan sebenarnya sama saja menguraikan sejarah pada umumnya. Dengan pengertian bahwa sejarah pedesaan ialah sejarah tentang apa saja dengan bidang garapan desa, masyarakat petani dan ekonomi pertanian. Dengan catatan bahwa sejarah adalah catatan perubahan-perubahan, kita dapat melowongkan masalah kedalam berbagai kelompok: (1) bangunan fisik, (2) satuan sosial, (3) lembaga sosial, (4) hubungan sosial, dan (5) gejala psiko-kultural (Dadas Wati, dkk, 2016: 89)

Desa Talaga Besar terletak di wilayah Kecamatan Talaga Raya Kabupaten Buton Tengah, jika dilihat dari sisi sejarahnya Desa Talaga Besar merupakan desa yang tertua yang ada di wilayah adminstratif Kecamatan Talaga Raya. Bahkan pada awal terbentuknya Desa Talaga Besar masih bergabung dengan kabupaten induk yaitu Kabupaten Buton, dan jauh dari itu Desa Talaga Besar telah ada dan telah berstatus desa sejak tahun 1977. Secara geologis, letak wilayah Desa Talaga Besar berada pada satu wilayah kepulauan yang tersendiri, dengan wilayah yang cocok untuk bercocok tanam atau berkebun, selain itu kekayaan perairan laut dapat membangun sektor perikanan Desa Talaga Besar.

\section{METODE PENELITIAN}

Penelitian ini dilaksanakan di Desa Talaga Besar Kecamatan Talaga Raya Kabupaten Buton Tengah. Dengan menggunakan penelitian sejarah yang bersifat analisis deskriptif dengan pendekatan strukturis yang mempelajari dua domain yaitu domain peristiwa (event) dan domain struktural. Sumber sejarah yang digunakan dalam penelitian initerdiri atas: sumber tertulis, sumber lisan dan sumber visual. Prosedur yang digunakan dalam penelitian terdiri atas pertama Heuristik (Pengumpulan Data) yang terdiri dari Penelitian kepustakaan (library research), penelitian lapangan (field research), teknik ini terbagi menjadi tiga bahagian yakni Pengamatan (observasi), Wawancara (interview), yaitu teknik pengumpulan data dengan mengadakan tanya jawab secara mendalam dengan lima orang informan yang mengetahui dan dapat memberikan gambaran tentang sejarah Desa Talaga Besar, sehingga dapat diperoleh data-data dan informasi yang dibutuhkan, studi dokumen, Kedua verifikasi (kritik sejarah) yang terdiri atas Kritik ekstern (kritik luar), Kritik intern (kritik dalam), interpretasi, yang terdiri dari Analisis dan Sintesis (menyatukan) ketiga yakni penulisan sejarah (Historiografi)

\section{HASIL PENELITIAN DAN PEMBAHASAN \\ Latar Belakang Terbentuknya Desa Talaga Besar Kecamatan Talaga Raya Kabuppaten Buton Tengah}

Berbicara latar belakang terbentuknya sebuah desa berarti kita akan membahas kejadiankejadian dimasa lampau sebelum terbentuknya desa tersebut. Demekian halnya, untuk mengetahui 
latar belakang terbentuknya Desa Talaga Besar, penting kiranya di kemukakan peristiwa-peristiwa yang mengawali proses terbentuknya desa tersebut.

Lahirnya Desa Talaga Besar tidak terlepas dari adanya sekelompok masyarakat tani yang bermukiman disuatu tempat yang disebut Naw'u (kebun). Seiring bertambanya jumlah penduduk yang berkebun dan mulai disarankan adanya kepentingan-kepentingan bersama yang awalnya hanya mendirikan pondok-pondok untuk ditinggali sementara waktu kemudian berinisiatif untuk mendirkan rumah permanen sebagai tempat tinggal dan membentuk komonitas-komonitas dalam beriteraksi satu sama lain.

\section{Asal-Usul Penduduk Desa Talaga Besar}

Sebagai awal keberadaan manusia sebagai mahluk sosial bersifat dinamis, dalam arti selalu melakukan berbagai cara dalam memenuhi kebutuhan hidupnya dan mempertahankan kelangsungan hidup generasinya, sebagai akibat dari adanya berbagai aktifitas tersebut maka akan terjadi suatu perkembangan kehidupan mansyarakat terutama dari segi bertambahnya jumlah penduduk yang menghuni daerah tertentu khususnya daerah kepulauan Desa Talaga Besar.

Asal usul penduduk desa Talaga Besar sebagai penghuni pertama adalah suku Buton yang terdiri dari Wameo, kadatua, Siompu, dan Mawasangka umumnya hidup beda tempat yaitu pulau Talaga Kecil dan Talaga Besar. Dari dua kampung tersebut kemudia bersapakat melakukan musyawarah untuk membetuk suatu desa. Desa Talaga Besar terletak di wilayah Kecamatan Talaga Raya Kabupaten Buton Tengah, jika dilihat dari sisi sejarahnya Desa Talaga Besar merupakan desa yang tertua yang ada di wilayah adminstratif Kecamatan Talaga Raya. Bahkan pada awal terbentuknya Desa Talaga Besar masih bergabung dengan kabupaten induk yaitu Kabupaten Buton, dan jauh dari itu Desa Talaga Besar telah ada dan telah berstatus desa sejak tahun 1977. Secara geologis, letak wilayah Desa Talaga Besar berada pada satu wilayah kepulauan yang tersendiri, dengan wilayah yang cocok untuk bercocok tanam atau berkebun, selain itu kekayaan perairan laut dapat membangun sektor perikanan Desa Talaga Besar.

Desa Talaga Besar terbentuk pada tahun 1977 dari faktor penduduk atau masyarakat, orang Buton (Wameo, Kadatua, Siompu dan Mawasangka) mulai masuk diwilaya kampung Talaga sebelum terbentuknya desa, umumnya hidup dalam komunitas pekabua (memancing) dan poyinawu (berkebun). Mereka masuk berkebun setelah melihat tanah yang ada di Desa Talaga Besar sangat cocok dibukakan lahan perkebunan, maka orang-orang Buton yang masuk berkebun tertarik untuk berkebun dan bercocok tanam di Desa Talaga Besar, bahkan ada beberapa yang menetap dan menikah dengan masyarakat Kadatua, Siompu, Wameo dan Mawasangka yang ada di Desa Talaga Besar. Pada akhirnya Tahun 1977 orang Kadatua, Siompu, Wameo, dan Mawasangka makin ramai masuk di Desa Talaga Besar seiring dengan awal pengangkatan kepala desa yang pada saat itu dikepalai bapak La Daku. Suku Buton (Kadatua, Siompu, Wameo, dan Mawasangka), yang sudah menetap di Desa Talaga Besar dalam kehidupan sehari-hari terjalin hubungan yang baik hal ini menunjukan bahwa adanya kerja sama seperti musyawara pembentukan kampung Talaga Besar.

\section{Pembentukan Desa Talaga Besar}

Sebelum menjadi sebuah desa defenitif, wilayah Desa Talaga Besar merupakan bagian dari kampung Talaga yang masih dalam wilayah adiministrasi kecamatan Kabaena Timur. Dulu Desa Talaga mencakup wilayah Kampung Talaga Satu, Talaga Dua, dan Talaga Besar. Namun penulis akan membahas tentang terbentuknya Desa Talaga Besar dengan fase atau pasca kemerdekaan pada era 1977-2017. Desa Talaga yang dimekarkan serentak menjadi tiga (3) desa dari Kecamatan Kabaena Timur, Talaga Besar terbentuknya menjadi desa definitif pada Tahun 1977 melalui Surat Keputusan Gubernur Kepala Daerah Tingkat I Sulawesi Tenggara Nomor 379 Tahun 1977 Tentang Penetapan Desa Persiapan Hasil Pemecahan, Desa Talaga Besar Unit Pemukiman Transmigrasi (UPT) menjadi desa definitif, Wilayah Kabupaten Daerah Tingkat II Buton

Pemberian nama Desa Talaga Besar diambil dari salah satu teweu-tewe'u (telega-telaga) yang ada di Talaga Besar. Kata Tewe'u mungkin sepintas terdengar seperti Telaga yang berisikan air hujan dan atau yang mempunyai lubang menembus pemukaan laut sehingga di dalammnya 
terdapat Penyu dan udang, dan sampai sekarang masi di lestarikan oleh masyarakat Desa Talaga Besar dan sewaktu-waktu masyarakat meninikmati hasilnya. Telaga ini memiliki lebar 50 meter dengan tinggi sekitar 2-5 meter dan kedalaman dibawah tanah sekitar 3-4 meter. Telaga merupakan nama lain dari Tewe'u (bahasa Wolio) atau Kantinu dalam bahasa Pancananya,

Desa Talaga Besar awalnya hanya dijadikan tempat untuk berkebun atau bercocok tanam, misalnya menanam jagung dan ubi kayu sebagai makanan pokok masyarakat setempat dan pada umumnya masyarakat Buton. Karena seiring berjalannya waktu dan peradaban serta jumlah penduduk semakin bertambah banyak, Pemerintah daerah berinisiatif memekarkan desa Talaga Besar menjadi desa Difinitif. Persyaratan pembentukan salah satu desa sudah sepenuhnya dimiliki oleh Desa Talaga Besar seperti, jumlah penduduk, luas wilayah, sosial budaya dan kehidupan masyarakatnya. Sehinggga memudahkan pembentukan Desa Talaga Besar dengan diprakarsai oleh tokoh-tokoh masyarakat. Adapun uraian persyaratan pembentukan Desa Talaga Besar adalah sebagai berikut:

\section{a. Faktor Jumlah Penduduk}

Penduduk ini sangat penting dalam mengelolah secara komperhensif potensi yang ada. Pelaksanaan pemerintah dibutuhkan orang-orang yang berkompoten di bidang pemerintahan sebab jika disuatu daerah tidak memiliki penduduk, maka kemungkinan tidak ada aktifitas kegiatan yang dijalankan, penduduk inilah sebagai pendukung aktifitas kegiatan manusia dan sekaligus faktor pendukung terbentuknya sebuah desa. Dalam Undang-Undang Desa Nomor 6 Tahun 2014 jumlah penduduk merupakan salah satu faktor yang sangat mendukung terbentuknya desa, kriteria atau persyaratan minimal jumlah penduduk sebanyak 2.084 jiwa yang terdiri $567 \mathrm{KK}$, khususnya untuk daerah Sulawesi Tenggara, dalam pembentukan desa pada tahun 1977 tersebut Desa Talaga Besar sudah dibentuk, dimana pada tahun tersebut Desa Talaga Besar telah resmi menjadi sebuah desa.

b. Faktor Luas Wilayah

Dukungan faktor luas wilayah dalam rangka pelaksanaan pemerintah baik di tingkat negara, provinsi, kabupaten/kota, kecamatan, maupun di tingkat desa atau kelurahan merupakan suatu hal yang sangat penting, luas wilaya Desa Talaga Besar 21,67 km2. Demikian pulah halnya dengan latar belakang terbentuknya Desa Talaga Besar dengan kondisi wilayah besarta potensi yang ada di dalamnya karnah pertimbangan yang cukup strategis sehingga memungkinkan mudahnya berhubungan antara pemerintah Desa Talaga Besar dan pemerintah kabupaten bahkan dengan provinsi yang dimana Desa Talaga Besar yang tadinya hanya sebuah tempat persinggahan kemudian berdiri menjadi sebuah desa.

c. Faktor Sosial Budaya

Faktor sosial budaya merupakan faktor pendukung pembentukan satu desa. Melalui kegiatan pembangunan dalam bidang sosial budaya di harapkan antara mansyarakat yang ada di Desa Talaga Besar baik yang beragam suku yang ada didalamnya maupun pemerintah terjalin hubungan yang harmonis, hormat menghormati, guna dalam menciptakan suasana yang harmonis dan kondusif sehingga dapat meningkatkan taraf hidup dan kesejahteraan masyarakat yang ada di Desa Talaga Besar. Kegiatan pembangunan dalam bidang sosial budaya di Desa Talaga Besar sudah terwujud sebelum Desa Talaga Besar definitif, pembangunan yang dimaksud adalah sistim budaya posaangu tabangu lipu (kerjasama), seiring dilakukan apabila ada kegiatan-kegiatan kerja bakti dalam membangun rumah wargah yang dalam lingkukan Desa Talaga Besar sehingga dapat terwujud hubungan timbal balik yang harmonis dalam lingkungan warga masyarakat Desa Talaga Besar.

d. Faktor Sosial Politik

Pemekaran desa adalah pembentukan desa baru yang memiliki wilayah administratif baru ditingkat kecamatan dari desa induknya. Pada dasarnya secara definisi pemekaran desa adalah bentuk usaha dari pemerintah dalam melakukan pemerataan dan pembagian wilayah ketingkat yang lebih merata dan rapi, agar tidak terjadinya tumpang tindih, baik secara administratif, maupun secara sumber potensi yang ada. Namun jauh dari itu pemekaran desa sebenarnya memiliki tujuan 
yang sangat mulia yang mengacu pada keinginan sejumlah masyarakat setempat untuk meningkatkan taraf kesejahteraan masyarakat melalui pemerintahan yang otonom.

Calon pembentukan Desa Talaga Besar yang terdiri atas empat dusun yaitu Dusun Banabungi, Dusun Bage, Dusun Peropa, dan Dusun Kalia-lia memiliki sejumlah individu yang berstatus penduduk sebanyak 2.084 jiwa yang merupakan sel-sel masyarakat yang dinamis. Struktur sosial masyarakat Desa Talaga Besar memiliki hubungan yang dinamis yang dapat membangun hubungan-hubungan sosial, serta hubungna politik yang berupa tingkah laku kolektif. Namun perlu difahami struktur sosial keempat dusun memiliki tingkah laku sosial yang tidak berbeda.

Pada dasarnya masyarakat di empat dusun memiliki pandangan hidup yang sama, yakni perlu ada kemajuan dalam hidup berbudaya sehingga integrasi dapat terjalin dengan baik diantara masyarakat yang ada. Adanya saling ketergantungan antara Dusun Banabungi, Bagea, Peropa, dengan Dusun Kalia-lia dalam hal pola-pola budaya masyarakat yang mayoritas nelayan dan bertani sehingga dalam pola budaya yang perlu dibangun yaitu memiliki lembaga sosial yang lebih besar untuk membentuk sebuah desa yaitu Desa Talaga Besar. Sehingga representasi politik yang selama ini kurang terakomodir bisa terealisasi dengan baik.

Selain itu, pembentukan Desa Talaga Besar bisa disetujui dengan cepat oleh Kepala Daerah Tingkat I Sulawesi Tenggara tentunya tidak terlepas atas keinginan yang sama oleh pemerintah desa induk yang dengan cepat merespon keinginan masyarakat Desa Talaga Besar untuk dijadikan sebagai desa yang definitif. Kondisi sosial politik masyarakat Desa Talaga Besar sesuai yang dipaparkan diatas tentu tidak akan memberikan kontribusi lebih jika tidak memenuhi syarat utama yang tertuang dalam pasal 8 Undang-Undang Nomor 6 Tahun 2014 Tentang Desa.

Sebelum menjadi sebuah desa definitif, wilaya Desa Talaga Besar merupakan bagian dari kampung Talaga yang masih dalam wilayah adiministrasi kecamatan Kabaena Timur sebelum mekar menjadi Kecamatan Talaga Raya dan Pemberian nama Desa Talaga Besar diambil dari salah satu Tewe'u-tewe'u (Telaga-Telaga) yang ada di Talaga Besar. Serta di dukung dengan faktor penduduk, faktor luas wilayah, faktor sosial budaya, dan faktor sosial politik.

\section{Perkembangan Desa Talaga Besar di Kecamatan Talaga Raya Kabupaten Buton Tengah Tahun 1977- 2017}

Setiap manusia yang menempati hunian dalam hal ini desa pada umumnya mempunyai cita-cita dan tekad untuk meningkatkan kualitas hidup. Hal ini pada prinsipsnya timbul dalam diri manusia atau seseorang karena adanya rasa kekurangan dari kebutuhan itu, maka manusia terdorong untuk berusaha dan terarah dengan sadar guna mencapai tujuannya. Pada saat tujuan tercapai berarti telah terjadi kondisi keseimbangan dalam diri sesorang baik dalam pemenuhan kebutuhan fisiologi maupun psikologis. Melihat penjelasan di atas telah sekian lamanya masyarakat mendiami Desa Talaga Besar maka nampak perkembangan kehidupan mereka terutama dalam bidang:

\section{Dalam Bidang Ekonomi}

Pasar Desa Talaga Besar yang terletak didekat pesisir pantai dan pelabuhan sehinnga desadesa tetangga yang menjadi tempat transaksi jual-beli hasil-hasil penjualannya dan hasil penjualan barang-barang seperti pakaian, sembako, aksesoris, dan sayur-sayuran yang didatangkan dari berbagai macam kepulawan seperti kabaena, mawasangka, kian mengalami kemajuan serta perkembangan dan berdampak positif bagi lancarnya perputaran mata uang yang ada di Desa Talag Besar. Demikian pula dengan profesi-profesi lain makin hari makin nampak misalnya petani, tukang kayu, pekerja bangunan, dan pekerjaan lain yang dapat memberikan hasil yang lebih baik untuk menghidupi keluarganya. Kenyataan ini timbul karena adanya dukungan dari kondisi alam di daerah Desa Talaga Besar yang ada.

a. Pertanian

Sebagaian besar masyarakat Desa Talaga Besar menggantungkan hidupnya dibidang pertanian yang merupakan hasil budaya yang telah dilakukan dan dikembangkan secara turun 
temurun, apabila dilihat dari kondisi lingkungan alam dan penguasaan teknologi serta peralatan pertanian yang masih sederhana, maka dengan terjun dibidang pertanian tersebut memang sangat cocok untuk dipilih sebagai salah satu alternatif pemenuhan kebutuhan kehidupan masyarakat.

Kondisi Desa Talaga Besar memang sangat menguntungkan bagi pengembangan sektor pertanian, terutama dengan pemilihan tanaman jangka panjang. Karena tanahnya merupakan dataran yang berbukit dengan kondisiyang relatif subur serta cukupnya curah hujan. Dengan demikian pengembangan tanaman jangka panjang yang dilakukan oleh masyarakat sebenarnya merupakan usaha adaptasi dengan lingkungannya. Adanya curah hujan yang cukup di wilayah Desa Talaga Besar, mendorong pengerjaan pembukaan lahan pertanian untuk tanaman jangka panjang seperti, jambu mete, ubi kayu Serta pengolahan lahan untuk tanaman jangka pendek seperti jagung, yang disesuaikan dengan datangnya musim hujan. Aktifitas masyarakat Desa Talaga Besar akan tercurah sepenuhnya di lahan mereka apabila masa pengerjaan lahan pertanian mulai dilakukan. Mengingat ada sebagian masyarakat Desa Talaga Besar antara rumah dan kebun mereka cukup jauh, maka biasanya mereka membuat pondok-pondok untuk tempat tinggal sememntara di kebun, mereka selama masa pengerjaan lahan sambil menunggu dan merawat tanamannya masing-masing.

Ada beberapa tahapan pertanian yang bisa dilakukan oleh masyarakat Desa Talaga Besar yaitu: Pertama, tahap persiapan yaitu persiapan lahan garapan dilakukan pada akhir musim kemarau, yaitu sekitar bulan Mei sampai Oktober.Pada masa ini masyarakat membersihkan lahan mereka dari semak belukar. Biasanya pembersihan lahan pertanian dilakukan dengan cara membakar semak-semak tersebut, namun terlebih dahulu membersihkan bagian pinggir sepanjang batas lahan mereka supaya pembakaran lahan tersebut tidak merambat ke lahan milik orang lain. Teknik pembersihan lahan pertanian dengan pembakaran ini dinilai cukup praktis karena relatif tanah lahan pertanian mereka tidak rata dan terkadang cukup terjal. Setelah lahan mereka bersih dari semak belukar, maka lahan-lahan tersebut tinggal dibersihkan dari sisa-sisa pembakaran sehingga selanjutnya siap untuk ditanami.Sambil menunggu datangnya hujan, maka lubang persemaian untuk tanaman baik tanaman jangka panjang seperti kelapa maupun tanaman jangka pendek seperti jagung mulai dibuat dengan digali untuk menanam jagung.

Kedua, tahap penanaman yaitu pada tahap ini lahan tersebut mulai ditanami dengan berbagai jenis tanaman baik tanaman jangka panjang maupun tanaman jangka pendek pada awal musim hujan. Dalam masa penanaman semua anggota keluarga ini terlibat secara penuh terkecuali anggota keluarga yang masih anak-anak dan yang berusia lanjut, bahkan terkadang ada anggota keluarga lain yang turut serta, dalam hal ini gotong royong (Poangka angkataka).

Ketiga, tahap perawatan yaitu setelah lahan ditanami, maka tanaman tersebut harus selalu dijaga dari gangguan berbagai jenis binatang liar atau jenis binatang piaraan yang memang menurut kebiasaan dibiarkan dilepas begitu saja oleh pemiliknya. Untuk menjaga dari gangguan binatang maka lahan yang sudah ditanami tersebut dibuatkan pagar dari batu gunung atau kayu disekelilingnya.

Keempat, adalah tahap pemetikan hasil yaitu hasil dari tanaman di kebun diharapkan dapat memenuhi kebutuhan pokok sehari-hari dan kebutuhan tambahan. Selain tanaman yang dibahas di atas masyarakat Desa Talaga Besar juga menanam berbagai jenis tanaman untuk mendukung keperluan rumah tangga mereka di kebun sekitar rumah mereka seperti; tomat, ubi kayu dan sayurmayur. Kegiatan ini biasanya dijalankan di sela-sela kegiatan perladangan mereka yang dimana kaum wanita yang berperan aktif.

b. Perdagangan

Dalam hal perdagangan oleh masyarakat Desa Talaga Besar dilakukan dengan penjualan hasil produksi panen dalam skala besar, dan yang menjadi langganan berbisnis adalah orang-orang Desa Talaga Besar yang kebanyakan mempunyai kendaraan laut (kapal bodi) dan relasi bisnis di pasar kota maupun pasar tradisional yang ada diberbagai desa tetangga.

Barang yang dijadikan bisnis dilingkup Desa Talaga Besar dengan relasi bisnis mereka adalah berupa hasil penangkapan nelayan seperti ikan, lobster dan gurita.Kegiatan usaha ini yang 
dijadikan sebagai kegiatan yang paling digemari oleh sebagian besar masyarakat Desa Talaga Besar pada khususnya dan masyarakat kecamatan Talaga Raya pada umumnya.Karena hasil inilah yang sangat dibutuhkan oleh masyarakat Desa Talaga Besar yang berkecimpung di bidang perikanan. Alasan lain juga karena hasil ini berkesinambungan terus dan dikatakan musimnya berjalan terus sepanjang masa. Ikan, lobster dan gurita merupakan penunjang ekonomi atau merupakan mata pencaharian yang paling menunjang bagi masyarakat Desa Talaga Besar. Berdagang memang peranan yang sangat penting dalam kehidupan masyarakat Desa Talaga Besar, karena hal ini merupakan salah satu bidang usaha yang dapat membawa hasil yang cukup lumayan dan akses untuk memasarkan hasil panangkapan tersebut tidak begitu sulit. Sehingga tak ketinggalan pula masyarakat lainnya terjun dalam bidang ini. Dengan demikian barang dagangan lain pun ikut dijajakan di Desa Talaga Besar. Misalnya kebutuhan primer dan kebutuhan sekunder hal ini dapat diperoleh di kios-kios dan pasar yang berada di Desa Talaga Besar

\section{Dalam Bidang Sosial}

Hubungan sosial kemasyarakatan antara warga Desa Talaga Besar berjalan cukup harmonis, bahkan boleh dikatakan sudah dianggap sebagai saudara sendiri.Prinsip mereka bergaul adalah mencari teman tanpa pandang bulu. Pernyataan ini menunjukan bahwa pada mulanya hubungan antara masyarakat Desa Talaga Besar dengan menunjukan suatu keterikatan sosial yang lebih baik tanpa memandang perbedaan status sosial.Terbukti dengan adanya masyarakat pendatang dari desa lainnya yang menikah dengan masyarakat Desa Talaga Besar. Bahkan kebanyakan masyarakat pendatang dari desa lain yang menikah dengan masyarakat Desa Talaga Besar sudah menetap dan menjadi warga Desa Talaga Besar, hal ini juga didukung dengan pergaulan pendatang yang cepat beradaptasi dengan masyarakat Desa Talaga Besar. Karena pergaulan yang begitu baik, serta semangat kerja yang luar biasa, maka pendatang ini dikenal dan selalu menjadi sahabat yang baik oleh masyarakat pribumi.

Perkembangan sosial yang diperlihatkan oleh masyarakat pendatang nampak pula dengan adanya adaptasi dengan masyarakat Desa Talaga Besar terbukti dengan kerja sama dalam melaksanakan kegiatan-kegiatan sosial misalnya: kerja bakti yang sudah menjadi rutinitas di Desa Talaga Besar, dan gotong royong membuat jalan-jalan usaha tani dan bila ada yang mendirikan rumah tempat tinggal bahkan dalam proses pengolahan lahan untuk pertanian pun pendatang ikut terlibat. Hal ini dikenal dengan sebutan poyiinawu.

3. Dalam Bidang Pendidikan

Sejalan dengan perkembangan masyarakat sosial masyarakat Desa Talaga Besar yang semakin meningkat, maka kepentingan-kepentingan keluarga mulai dapat terpenuhi dengan baik, bahkan anak-anak mereka sudah dapat menikmati pendidikan dengan baik dan sempurnah, mulai dari pendidikan SD, sampai pada tingkat pendidikan tinggi terutama di lingkup Universitas. Perkembangan pendidikan di Desa Talaga Besar pada khususnya dan kecamatan Talaga Raya pada umumnya mengalami perkembangan pendidikan yang boleh dikatakan sudah cukup baik. Terbukti dengan adanya beberapa sarana pendidikan yang terdapat di Desa Talaga Besar antara lain TK dan SD, SMP, dan SMA. Dengan adanya sarana pendidikan tersebut maka jumlah anak sekolah tiap tahunnya terus bertambah.

Adanya kesadaran masyarakat yang demikian itu, dapat terlihat dari sikap dan pola pikir serta wawasan mereka terhadap masalah pendidikan. Masalah pendidikan tidak dapat dilepas pisahkan dari kehidupan seseorang, dan pendidikan mempunya hubungan secara langsung dengan kehidupan manusia. Karena dengan pendidikan manusia bisa memperoleh suatu penghidupan yang layak dalam memenuhi kebutuhannya. Pendidikan juga dapat mencerdaskan kehidupan bangsa. Bila kita simak pandangan di atas, bahwa mereka tidak menginginkan pada suatu kelak nanti anakanak mereka harus hidup seperti yang mereka telah alami, dimana mereka pada umumnya hanya memperoleh pendidikan sampai pada tingkat Sekolah Dasar. Sehingga sulit bagi mereka untuk 
memperoleh pekerjaan yang layak bagi kehidupannya di era perkembangan dan persaingan IPTEK dewasa ini.

4. Dalam Bidang Sarana dan Prasarana

Untuk menunjang taraf hidup masyarakat Desa Talaga Besar, pemerintah menyadari harus membangun sejumlah infrastruktur seperti jalan usaha tani yang ada di desa yang menghubungkan akses jalan untuk penyaluran hasil pertanian untuk dijual dipasar-pasar tradisional. Hal ini untuk memudahkan arus transportasi, sehingga memudahkan masyarakat setempat dalam memasarkan hasil produksi pertaniannya yang menjadi andalan dalam memenuhi kebutuhan sehari-hari. Kemudian untuk bidang pelayanan masyarakat, dalam hal struktur pemerintahan sudah cukup bagus. Pemerintah juga membangun sarana pemerintahan sebagai pusat pelayanan, baik bidang pengurusan administrasi kependudukan, maupun sosialisasi penyuluhan pertanian. Hal ini akan lebih mempermudah mengedukasi masyarakat dalam hal kegiatan pertanian ditambah juga dengan adanya bantuan seperti bibit pertanian dan alat-alat untuk pengolahan lahan pertanian ini sangat membantu masyarakat setempat untuk lebih meningkatkan hasil produksi pertaniannya. Hingga saat ini sejumlah program pemerintah seperti program nasional pemberdayaan masyaraka (PNPM) dan Dana Desa (DD) terealisasi dengan baik sesuai dengan sasarannya seperti pembuatan jalan usaha tani dan pembuatan bak penampungan air Bersih.

Dengan adanya jalan usaha tani maka akses menuju ke kebun mereka tidak lagi memakan waktu yang lama, seperti sebelumnya hanya bisa dilalui dengan berjalan kaki setelah adanya jalan usaha tani sudah bisa dilalui dengan menggunakan roda empat (mobil) dan roda dua (sepeda dan motor). Ditambah dengan adanya bak penampung air bersi, masyarakat tidak lagi kesulitan masalah air bersih untuk keperluan memasak sudah bisa didapatkan di dalam rumah. Selain itu pemerintah membangun fasilitas kesehatan, berupa puskesmas pembantu untuk memudahkan pelayanan kesehatan masyarakat. Sehingga soal pengobatan kesehatan dasar masyarakat tidak lagi harus menuju ke kota yang aksesnya cukup jauh dan menggunakan transportasi kapal dari Desa Talaga Besar. Hingga dewasa ini dengan jumlah para medis yang ada di Desa Talaga Besar membuat masyarakat sadar betapa pentingnya kesehatan, dengan adanya puskesmas dan posiandu pembantu membuat masyarakat tidak lagi menggantungkan diri kepada dukun setempat yang selama ini dipercaya dalam hal penyembuhan kesehatan.

Setelah melihat perkembangan Desa Talaga Besar yang cukup signifikan, di tambah dengan faktor penduduk, sumber daya manusia dan sumber daya alam serta luas wilayah sudah memenuhi syarat makah Desa Talaga Besar memekarkan Desa Kokoe menjadi satu desa.

Tabel 4. Kronologi Pembangunan Desa Talaga Besar

\begin{tabular}{ccl}
\hline No. & Tahun & Kegiatan Pembangunan \\
1 & 1978 & Pembangunan Balai Desa \\
2 & 1984 & Pembangunan Mesjid Babusalam \\
4 & 1984 & Pembangunan SDN 1 Talaga Besar \\
5 & 1993 & Pembangunan Pustu Desa Talaga Besar \\
6 & 2006 & Pembangunan SMPN 2 Talaga Raya \\
7 & 2013 & Pembangunan SMAN 2 Talaga Raya \\
8 & 2015 & Pengadaan Mesin Pembangkit Listrik ( Diesel) \\
9 & 2016 & Pengadaan Mesin PLTS \\
10 & 2017 & Pembangunan Talud \\
11 & 2012 & Pembangunan PAUD \\
12 & 2017 & Pembangunan Jalan Rambat Beton \\
\hline
\end{tabular}

Sumber Data: Kantor Desa Talaga Besar 2017 
Berdasarkan koronologis diatas bahwa pembangunan infrastruktur Desa Talaga Besar dari tahun 1978 dalam 15 tahun terakhir telah membambungun Balai Desa, mesjid, sarana pendidikan SD, dan Pustu, sendangkan tahun 2006 dalam 11 tahun terakhir telah membangun PAUD, sarana pendidikan SMP, SMA, LISTRIK, Rambat beton jalan tani, dan talud jika dilihat dari segi pembangunan Desa Talaga Besar mengalami perkembangan dan kemajuan dari awal tahun pembentukannya sampai saat ini

\section{KESIMPULAN}

Berdasarkan uraian hasil penelitian dan pembahasan seperti telah dipaparkan pada bab sebelumnya, maka dapat ditarik beberapaa kesimpulan sebagai berikut : pertama sebelum menjadi sebuah desa defenitif, wilayah Desa Talaga Besar merupakan bagian dari kampung Talaga yang masih dalam wilayah administrasi kecamatan Kabaena Timur sebelum mekar menjadi Kecamatan Talaga Raya dan Pemberian nama Desa Talaga Besar diambil dari salah satu Tewe'u-tewe'u (Telaga-Telaga) yang ada di Talaga Besar. Selain itu juga didukung dengan faktor penduduk, faktor luas wilayah, faktor sosial budaya, dan faktor sosial politik. Kedua perkembangan Desa Talaga Besar Kecamatan Talaga Raya Kabupaten Buton Tengah dari Tahun 1977-2017 dalam bidang ekonomi pasar Desa Talaga Besar yang terletak didekat pesisir pantai dan pelabuhan sehingga desa-desa tetangga yang menjadi tempat transaksi jual-beli hasil-hasil penjualannya dan hasil penjualan barang-barang seperti pakaian, sembako, aksesoris, dan sayur-sayuran yang didatangkan dari berbagai macam kepulauan seperti Kabaena dan Mawasangka, kian mengalami kemajuan serta perkembangan dan berdampak positif bagi lancarnya perputaran mata uang yang ada di Desa Talaga Besar. Bidang Sosial adalah kerja bakti yang sudah menjadi rutinitas di Desa Talaga Besar, dan gotong royong membuat jalan-jalan usaha tani dan bila ada yang mendirikan rumah tempat tinggal bahkan dalam proses pengolahan lahan untuk pertanian pun pendatang ikut terlibat. Bidang pendidikan yaitu perkembangan pendidikan di Desa Talaga Besar pada khususnya dan Kecamatan Talaga Raya pada umumnya mengalami perkembangan pendidikan yang boleh dikatakan sudah cukup baik. Terbukti dengan adanya beberapa sarana pendidikan yang terdapat di Desa Talaga Besar antara lain TK, SD, SMP, dan SMA. Dengan adanya sarana pendidikan tersebut maka jumlah anak sekolah tiap tahunnya terus bertambah, dan infrastruktur (sarana dan prasarana) yaitu pemerintah membangun fasilitas sarana kesehatan, pasar desa, sarana pendidikan, jalan rambat beton, sarana listrik dan sarana lainnya yang memudakan masyakat seperti sarana pelayanan publik lainnya

\section{DAFTAR PUSTAKA}

Harsono. 1984. Pengantar Antropologi. Bandung: Bina Cipta

Kuntowijoyo. 2003. Metodologi Sejarah. Yogyakarta: Tiara Wicana

Sapoetra, Karto. 1986. Desa dan Daerah. Jakarta: Bina Aksara

Siagian, P. Sondang. 1988. Pokok-Pokok Pembangunan Masyarakat Desa. Bandung: Citra Aditya Bakti

Jumriatin, Mursidin T, 2019. Sejarah Desa Taipa Kecamatan Lembo Kabupaten Konawe Utara Tahun 1978-20171. Jurnal Historical Education: Jurnal Penelitian Pendidikan Sejarah Volume 4 No. 1. Hal. 57-64.

Dadas Wati, Ali Hadara, La Ode Baenawi. 2016. Sejarah Kampung Dandila Menjadi Desa Marobea Kecamatan Sawerigadi Kabupaten Muna Barat (1960-2015). Jurnal Historical Education: Jurnal Penelitian Pendidikan Sejarah Vol. 1 No. 1 Hal. 88-97 